\title{
A novel strategy for preparing \\ nanoporous biphasic calcium phosphate of controlled composition via a modified nanoparticle-assembly method
}

Keiko Fujiwara ${ }^{1, *}$, Masahiro Okada, ${ }^{2, *}$, Shoji Takeda $^{2}$, Naoyuki Matsumoto ${ }^{1}$

${ }^{1}$ Graduate School of Dentistry, Department of Orthodontics, Osaka Dental University, 8-1

Kuzuha-Hanazono, Hirakata, Osaka 573-1121, Japan

${ }^{2}$ Department of Biomaterials, Osaka Dental University, 8-1 Kuzuha-Hanazono, Hirakata, Osaka 573-1121, Japan

*Corresponding authors:

K. Fujiwara: keiko.reboot@gmail.com (Tel: +81-72-864-3078)

M. Okada: okada-m@cc.osaka-dent.ac.jp (Tel: +81-72-864-3111) 


\begin{abstract}
Biphasic calcium phosphate (BCP) consisting of hydroxyapatite (HAp) and $\beta$-tricalcium phosphate is usually prepared by thermal decomposition of calcium-deficient HAp (CDHAp). However, the calcium deficiency and morphology of CDHAp are difficult to manipulate in parallel. In this study, we report a novel strategy for controlling the composition of nanoporous BCP by using only CDHAp nanoparticles with specific properties $(\mathrm{Ca} / \mathrm{P}$ molar ratio, 1.61 ; particle size, $50 \mathrm{~nm}$ ) as a building block and by adjusting the calcium deficiency of the nanoparticle-assembled CDHAp (Ca/P molar ratio, 1.50-1.67; pore size, $8 \mathrm{~nm}$ ) with the addition of water-soluble $\mathrm{Ca}\left(\mathrm{NO}_{3}\right)_{2}$ or $\left(\mathrm{NH}_{4}\right)_{2} \mathrm{HPO}_{4}$. After thermal treatment at $1000^{\circ} \mathrm{C}$, the composition of $\mathrm{BCP}$ could be predictably controlled by adjusting the $\mathrm{Ca} / \mathrm{P}$ ratio of the nanoparticle-assembled CDHAp. Changes in the $\mathrm{Ca} / \mathrm{P}$ ratio did not significantly affect the surface morphology of $\mathrm{BCP}$, but the grain size $(210-300 \mathrm{~nm})$ and pore size $(140-170 \mathrm{~nm})$ tended to increase slightly as the $\mathrm{Ca} / \mathrm{P}$ ratio decreased. The porosity significantly decreased upon the addition of Ca salts (porosity, 20\%) or $\mathrm{PO}_{4}$ salts (porosity, 14\%) compared with that of the sample without additives (porosity, 53\%). In vitro tests demonstrated enhanced cell adhesion on nanoporous BCP compared with densely sintered pure HAp, and cell differentiation was promoted on the nanoporous pure HAp.
\end{abstract}

Keywords: calcium phosphate; nanoparticle; assembly; nanopore; osteoblast 


\section{Introduction}

Calcium phosphate-based bioceramics have been proven to have a great potential for biological applications [1-3]. Among these bioceramics, particular attention has been given to hydroxyapatite (HAp: $\mathrm{Ca}_{10}\left(\mathrm{PO}_{4}\right)_{6}(\mathrm{OH})_{2} ; \mathrm{Ca} / \mathrm{P}$ molar ratio, 1.67) owing to its bioactivity, and to $\beta$-tricalcium phosphate $\left(\beta\right.$-TCP: $\mathrm{Ca}_{3}\left(\mathrm{PO}_{4}\right)_{2} ; \mathrm{Ca} / \mathrm{P}$ molar ratio, 1.50$)$ owing to its resorbability [4]. To achieve optimum resorbability, biphasic calcium phosphate (BCP: a mixture of HA and $\beta$-TCP) was developed [5-9]. Initial studies on BCP reported by LeGeros et al. demonstrated that the bioactivity of $\mathrm{BCP}$ can be controlled by manipulating the composition (i.e., HA/ $\beta$-TCP ratio) of $\mathrm{BCP}[7,8]$.

The most common method to prepare $\mathrm{BCP}$ is the thermal decomposition of nonstoichiometric calcium-deficient HAp $\left(\mathrm{CDHAp} ; \mathrm{Ca}_{10-x}\left(\mathrm{HPO}_{4}\right)_{x}\left(\mathrm{PO}_{4}\right)_{6-x}(\mathrm{OH})_{2-x} ; 0<x<1\right)$ at temperatures greater than $700^{\circ} \mathrm{C}$ [10]. The composition of $\mathrm{BCP}$ obtained after thermal treatment depends on the calcium deficiency of CDHAp and the treatment temperature $[9,10]$. Although CDHAp is usually prepared via wet chemical processes by manipulating reaction conditions (such as initial $\mathrm{Ca} / \mathrm{P}$ value, $\mathrm{pH}$, and temperature), predicting the calcium deficiency $(\mathrm{Ca} / \mathrm{P}$ ratio) is difficult and the particle morphological characteristics (i.e., size and shape) also vary depending on the reaction conditions [9-12]. Recently, Descamps et al. fabricated densely sintered BCP samples with well-controlled compositions and almost uniform morphology (grain size, $0.67-0.79 \mu \mathrm{m}$ ) by applying hot isostatic pressing (HIP) sintering of CDHAp prepared by wet chemical processes under finely tuned conditions [13].

Other methods to prepare BCP include solid-state reactions of mixtures of $\mathrm{CaHPO}_{4} \cdot 2 \mathrm{H}_{2} \mathrm{O} / \mathrm{CaCO}_{3}[14,15], \mathrm{Ca}_{3}\left(\mathrm{PO}_{4}\right)_{2} / \mathrm{Ca}(\mathrm{OH})_{2}[16]$, and $\mathrm{Ca}\left(\mathrm{H}_{2} \mathrm{PO}_{4}\right)_{2} \cdot \mathrm{H}_{2} \mathrm{O} / \mathrm{CaCO}_{3}[17,18]$. The sintering of a mixture of pure (stoichiometric) HAp powders and pure $\beta$-TCP powders has 
also been developed to easily control the composition of the resultant BCP $[19,20]$. However, the abovementioned solid-state reactions and sintering (i.e., mixing of different sized particles) are not recommended for the preparation of $\mathrm{BCP}$ with reproducible compositions and homogeneous crystal distributions [1].

Recently, nanostructured calcium phosphate ceramics have attracted interest owing to their improved bioactivity compared with the bioactivity of conventional ceramics [21-25]. For example, Webster et al. showed enhanced osteoclast-like cell adhesion and function on HAp ceramic surfaces that had nanometer-scale surface topography [21,22]. Sun et al. reported that nanophase HAp can more effectively promote the proliferation and osteogenic differentiation of periodontal ligament cells compared with dense HAp [23].

We developed a facile colloidal process for preparing nanoparticle-assembled CDHAp that involves drying of an aqueous dispersion of low-crystallinity CDHAp nanoparticles on an oil (flowable) substrate without template/binder molecules or high-temperature/pressure treatments [26]. In our previous study, we investigated thermally induced changes in nanoparticle-assembled CDHAp, and a nanoporous BCP (with pore sizes varying from 65-250 $\mathrm{nm})$ was obtained after thermal treatment at greater than $800^{\circ} \mathrm{C}$ [27]. In this study, we hypothesized that the composition of nanoporous $\mathrm{BCP}$ could be controlled by a thermal treatment of nanoparticle-assembled CDHAp with $\mathrm{Ca} / \mathrm{P}$ ratios that were manipulated during nanoparticle assembly - that is, by using only a certain type of CDHAp nanoparticles with specific properties as a building block and by adjusting the $\mathrm{Ca} / \mathrm{P}$ ratio via the addition of water-soluble $\mathrm{Ca}$ or $\mathrm{PO}_{4}$ salts to the aqueous dispersion of CDHAp nanoparticles, the $\mathrm{Ca}$ or $\mathrm{PO}_{4}$ salts are expected to be homogeneously distributed in the nanopores of nanoparticle-assembled CDHAp (prepared by drying the aqueous dispersion of the CDHAp nanoparticles after 
water-soluble $\mathrm{Ca}$ or $\mathrm{PO}_{4}$ salts were homogeneously dissolved). Hence, a homogeneous reaction between CDHAp nanoparticles and the $\mathrm{Ca}$ or $\mathrm{PO}_{4}$ salts could be achieved, and the resultant nanoporous BCP samples with controlled compositions could have the same surface morphology (i.e., surface grain and pore sizes) because the original CDHAp nanoparticles have the same morphology.

The objective of this study was to investigate the effects of the addition of water-soluble $\mathrm{Ca}$ or $\mathrm{PO}_{4}$ salts to the nanoparticle-assembled CDHAp on the composition and morphology of nanoporous $\mathrm{BCP}$ after thermal treatment. The composition (i.e., HAp/ $\beta$-TCP ratio) was determined using X-ray diffraction (XRD), and the morphological characteristics (i.e., surface grain and pore sizes) were investigated using scanning electron microscopy (SEM) and mercury intrusion porosimetry, respectively. Cell adhesion and differentiation behaviors on nanoporous $\mathrm{BCP}$ samples were compared to investigate the influence of different $\mathrm{BCP}$ compositions with similar surface nanoporous structures.

\section{Experimental Section}

\subsection{Materials}

Unless stated otherwise, all materials were reagent grade and used as received from Wako Pure Chemical Industries, Ltd., Osaka, Japan. Milli-Q water (Millipore Corp., Bedford, MA) with a specific resistance of $18.2 \times 10^{6} \Omega \cdot \mathrm{cm}$ was used.

\subsection{Low-crystallinity CDHAp nanoparticles}

An aqueous solution of $\mathrm{Ca}\left(\mathrm{NO}_{3}\right)_{2} \cdot 4 \mathrm{H}_{2} \mathrm{O}(42 \mathrm{mM}, 800 \mathrm{~mL})$, for which the $\mathrm{pH}$ was adjusted to 12.0 by adding $28 \%$ ammonia solution, was poured into a $1-\mathrm{L}$ reactor equipped with 
a magnetic stirrer and an inlet for nitrogen gas. After the reactor temperature was equilibrated at room temperature, an aqueous solution of $\left(\mathrm{NH}_{4}\right)_{2} \mathrm{HPO}_{4}(100 \mathrm{mM}, 200 \mathrm{~mL})$ was added to the reactor within $5 \mathrm{~s}$, and the resultant mixture was stirred for another $24 \mathrm{~h}$. The resulting product was then washed five times by centrifugation with Milli-Q water, after which it was redispersed in water (solid content, 2.0 wt.\%).

The nanoparticles were observed using SEM (S-4800; Hitachi High Technologies Corp., Tokyo, Japan) at $5 \mathrm{kV}$ after the samples were dried on an aluminum stub at room temperature and sputter-coated with $\mathrm{Pt}-\mathrm{Pd}$ to minimize sample-charging problems. The number-averaged particle size $(n=50)$ was determined from SEM images.

The $\mathrm{Ca} / \mathrm{P}$ molar ratio of the nanoparticles was measured by inductively coupled plasma-atomic emission spectrometry (ICP-AES: SPS4000; Seiko Instrument Inc., Chiba, Japan). Calcium and phosphorus standard solutions for ICP-AES were purchased from Kanto Chemical Co., Inc. (Tokyo, Japan).

\subsection{Nanoporous BCP}

First, an amount of $\mathrm{Ca}\left(\mathrm{NO}_{3}\right)_{2} \cdot 4 \mathrm{H}_{2} \mathrm{O}\left(0.05-0.10 \mathrm{~g}\right.$ vs. $1 \mathrm{~g}$ of CDHAp) or $\left(\mathrm{NH}_{4}\right)_{2} \mathrm{HPO}_{4}$ (0.025-0.05 $\mathrm{g}$ vs. $1 \mathrm{~g}$ of CDHAp) was dissolved in the aqueous dispersion of low-crystallinity CDHAp (Ca/P molar ratio, 1.61) nanoparticles, and the $\mathrm{Ca} / \mathrm{P}$ molar ratio in the dispersion was adjusted to a predetermined value (1.50-1.67). After the dispersion was degassed under reduced pressure at room temperature for approximately $5 \mathrm{~min}, 3 \mathrm{~mL}$ of the dispersion was gently cast onto the center of a liquid substrate (pentadecane; $0.3 \mathrm{~mL}$ ) [26,27] in a polytetrafluoroethylene (PTFE) watch dish. The dish was subsequently placed in a thermostat drying oven at $60^{\circ} \mathrm{C}$ overnight. After the nanoparticle-assembled plate (diameter, $\sim 8 \mathrm{~mm}$ ) was 
dried, it was placed on an alumina crucible in a horizontal furnace at room temperature in air. The furnace was heated from room temperature to $1000^{\circ} \mathrm{C}$ at a heating rate of $10^{\circ} \mathrm{C} / \mathrm{min}$ and then maintained at $1000^{\circ} \mathrm{C}$ for $1 \mathrm{~h}$ in ambient air. The heater of the furnace was then automatically turned off, and the plate was naturally cooled in the furnace to room temperature.

The surfaces of the samples were observed by SEM (S-4800 SEM operated at $5 \mathrm{kV}$ ) after the samples were fixed onto an aluminum stub and sputter-coated with $\mathrm{Pt}-\mathrm{Pd}$. The surface porosity (percentage of the area covered by pores in the total area) and the grain size were determined from randomly selected SEM images $(n=3)$ with an image analyzing software (Image J; National Institutes of Health, Bethesda, MD).

The pore-size distributions, open porosities, specific surface areas, and apparent densities were determined via mercury intrusion porosimetry (AutoPore IV 9520; Micromeritics Instrument Corp., Norcross, GA) after the samples were dried under vacuum at $60^{\circ} \mathrm{C}$ for $24 \mathrm{~h}$. The percentage of the closed pores was calculated from the difference in the apparent and theoretical densities of the sample (Table 1).

To identify the crystal phases of the samples, powder XRD measurements were performed using XRD-6100 (Shimadzu Corp., Kyoto, Japan) equipped with a CuK $\alpha$ radiation source after the samples were ground using mortar and pestle. The weight ratio of $\beta$-TCP and HAp was determined from the peak intensity ratio of $\beta$-TCP(0210) and $\mathrm{HAp}(211)$ reflections. Before these determinations, XRD patterns of commercially available pure HAp (Kishida Chemical Co., Ltd., Osaka, Japan; used after calcination at $1000^{\circ} \mathrm{C}$ for $1 \mathrm{~h}$ ), $\beta$-TCP (Wako Pure Chemical Industries, Ltd.), and their mixtures (1/9, 3/7, 5/5, 7/3, and 9/1 weight ratios) were collected, and a linear relationship between the weight ratio and peak intensity ratio was confirmed for the preparation of the linear calibration curve. 


\subsection{Cell adhesion and differentiation}

For cell adhesion testing, five samples were prepared for each nanoporous BCP composition (HAp/ $\beta$-TCP ratios varied). As control samples, tissue culture polystyrene of a 48-well multiwell plate (Sumitomo Bakelite Co. Ltd., Tokyo, Japan) and dense HAp (porosity, 0\%; CELLYARD pellet; HOYA Corp. Tokyo, Japan) were used. MC3T3-E1 mouse preosteoblast cells (Lot No. 10F002; Health Protection Agency Culture Collections, Salisbury, UK) were cultured on each sample (approximately $5.0 \times 10^{4}$ cells/well; 780 cells $/ \mathrm{mm}^{2}$ ), which had been sterilized with ethylene oxide gas at $60^{\circ} \mathrm{C}$, in $500 \mu \mathrm{L}$ of an $\alpha$-minimum essential medium ( $\alpha$-MEM; Wako Pure Chemical Industries, Ltd.) supplemented with 10\% heat-inactivated fetal bovine serum (FBS; Lonza, Basel, Switzerland), $50 \mathrm{IU} / \mathrm{mL}$ penicillin, and $50 \mu \mathrm{g} / \mathrm{mL}$ streptomycin (Lonza) at $37^{\circ} \mathrm{C}$ for $3 \mathrm{~h}$ in a 48 -well multiwell plate. Each sample was washed by pipetting with a Dulbecco's phosphate-buffered saline (PBS: without Ca and Mg; pH 7.4; Wako Pure Chemical Industries, Ltd.) three times and placed in an unused well. Then, the number of cells that adhered on to the sample was counted by colorimetry using a microplate reader (SpectraMax M5; Molecular Devices, LLC., Sunnyvale, CA) at $450 \mathrm{~nm}$ after staining with a water-soluble tetrazolium salt (Cell Counting Kit-8; Dojindo Laboratories, Kumamoto, Japan). Data resulting from the tests are presented as means \pm standard errors of the mean $(n=5)$. Statistical comparisons were performed with the Student's $t$ test. The level of statistical significance was defined as $\mathrm{p}<0.05$.

For cell-differentiation tests, MC3T3-E1 cells (approximately $5.0 \times 10^{3}$ cells/well; 80 cells $/ \mathrm{mm}^{2}$ ) were cultured on each sample in $\alpha$-MEM for three days. The cells were then incubated in $500 \mu \mathrm{L}$ of a differentiation medium supplemented with osteoblast-inducer 
reagents ( 1 vol.\% ascorbic acid, 0.2 vol. $\%$ hydrocortisone, and 2 vol. $\% \beta$-glycerophosphate; Takara Bio Inc., Shiga, Japan), and the medium was exchanged twice a week. After 7-, 14-, or 21-day incubation, alkaline phosphatase (ALP) staining (TRACP \& ALP double-stain Kit; Takara Bio Inc.) was conducted according to the manufacturer's instructions.

\section{Results and Discussion}

\subsection{CDHAp nanoparticles and nanoparticle-assembled CDHAp}

Low-crystallinity CDHAp nanoparticles were prepared via a wet chemical process with $\mathrm{Ca}\left(\mathrm{NO}_{3}\right)_{2}$ and $\left(\mathrm{NH}_{4}\right)_{2} \mathrm{HPO}_{4}$. To obtain small particles, the reaction was conducted at a relatively low temperature $\left(20^{\circ} \mathrm{C}\right.$; room temperature) and high $\mathrm{pH}(12.0)$ [26]. According to the SEM observations, the CDHAp nanoparticles after centrifugal washing exhibited a spherical morphology with a diameter of $50 \mathrm{~nm}$ and polydispersed particle size distribution [particle size coefficient of variation $(\mathrm{Cv}), 21 \%]$. The $\mathrm{Ca} / \mathrm{P}$ molar ratio of the nanoparticles was 1.61 , as determined via ICP-AES measurement. The aqueous dispersion of the CDHAp nanoparticles (solid content, $2.0 \mathrm{wt} . \%$ ) was a viscous liquid, which was attributed to the formation of a network structure caused by particle-particle interactions [28] due to their small size (i.e., a large number of particles) and zwitterionic-charged HAp surfaces that consisted of $\mathrm{Ca}^{2+}, \mathrm{PO}_{4}{ }^{3-}$, and $\mathrm{OH}^{-}$ions. The formation of the nanoparticle network structure was likely responsible for the formation of nanosized pores after the particles were dried. Note that adding $\mathrm{Ca}^{2+}$ or $\mathrm{PO}_{4}{ }^{3-}$ salts changes the $\zeta$-potential of HAp surfaces [29]. We observed that the addition of $\mathrm{Ca}^{2+}$ or $\mathrm{PO}_{4}{ }^{3-}$ salts improved the dispersion stability of the CDHAp nanoparticles after ultrasonic irradiation, and the resulting nanoparticle-assembled CDHAp had a more densely-packed structure with smaller sized nanopores [26]. In the preparation of the nanoparticle-assembled 
CDHAp with the same nanoporous structures (and with varied $\mathrm{Ca} / \mathrm{P}$ ratios) in this study, ultrasonic irradiation of the CDHAp dispersion after adding $\mathrm{Ca}^{2+}$ or $\mathrm{PO}_{4}{ }^{3-}$ salts was not performed. As a result, the dispersion state (i.e., sedimentation behavior) of the Ca- or $\mathrm{PO}_{4}$-doped CDHAp dispersion that was not exposed to ultrasonic irradiation was apparently the same as that of the original dispersion without additives. However, as discussed below, the packing state of the nanoparticles inside the nanoparticle-assembled CDHAp might have been changed; that is, more densely packed structure might be obtained by adding $\mathrm{Ca}^{2+}$ or $\mathrm{PO}_{4}{ }^{3-}$ salts (see Section 3.3).

\subsection{Composition of nanoporous $B C P$}

After the nanoparticle-assembled plates (diameter, $\sim 8 \mathrm{~mm}$ ) with different $\mathrm{Ca} / \mathrm{P}$ ratios were prepared, they were thermally treated at $1000^{\circ} \mathrm{C}$ (heating rate of $10^{\circ} \mathrm{C} / \mathrm{min}$ ) for $1 \mathrm{~h} \mathrm{in}$ ambient air. In this study, the treatment temperature was fixed at $1000^{\circ} \mathrm{C}$ because our previous study [27] revealed that treatment at a lower temperature (e.g., $800^{\circ} \mathrm{C}$ ) is insufficient for complete conversion of CDHAp to $\mathrm{BCP}$ and treatment at a higher treatment (e.g., $\left.1100^{\circ} \mathrm{C}\right)$ leads to the formation of larger pores (around $250 \mathrm{~nm}$ ).

The XRD measurements of the samples before heat treatment showed a broad pattern for HAp, and no other calcium phosphate phases were detected (Supplementary Fig. S2). After thermal treatment at $1000^{\circ} \mathrm{C}$, several peaks became more distinct (the widths of the peaks became narrower), which indicates an increase in the crystallinity. When thermal treatment was performed without additives $(\mathrm{Ca} / \mathrm{P}$ molar ratio, 1.61$)$, an additional crystalline phase of $\beta$-TCP was observed (Fig. 1c; see also the open circle in Fig. 2). Experimental evidence [10] indicates that stoichiometric $\mathrm{HAp}(\mathrm{Ca} / \mathrm{P}=1.67$, molar ratio $)$ does not decompose at temperatures as high 
as $1200^{\circ} \mathrm{C}$, whereas CDHAp $(1.50<\mathrm{Ca} / \mathrm{P}<1.67)$ decomposes at temperatures above $700^{\circ} \mathrm{C}$ into a mixture of stoichiometric HAp and $\beta$-TCP according to the following reaction:

$\mathrm{Ca}_{10-x}\left(\mathrm{HPO}_{4}\right)_{x}\left(\mathrm{PO}_{4}\right)_{6-x}(\mathrm{OH})_{2-x}-->(1-x) \mathrm{Ca}_{10}\left(\mathrm{PO}_{4}\right)_{6}(\mathrm{OH})_{2}+3 x \beta-\mathrm{Ca}_{3}\left(\mathrm{PO}_{4}\right)_{2}+x \mathrm{H}_{2} \mathrm{O} \cdots .$.

The $\mathrm{Ca} / \mathrm{P}$ molar ratio calculated from the above equation (1) and the $\beta$-TCP content (34.7 wt.\%; see the open circle in Fig. 2) after thermal treatment without additives was 1.61, which corresponded to that $(\mathrm{Ca} / \mathrm{P}$ molar ratio, 1.61) measured via ICP-AES.

The $\beta$-TCP content was linearly (predictably) controlled by adjusting the $\mathrm{Ca} / \mathrm{P}$ ratio of nanoparticle-assembled CDHAp (Fig. 2). That is, the $\beta$-TCP content decreased when water soluble $\mathrm{Ca}\left(\mathrm{NO}_{3}\right)_{2}$ was added to an aqueous dispersion of low-crystallinity CDHAp nanoparticles (Fig. 1b), and phase pure HAp was obtained after thermal treatment at a $\mathrm{Ca} / \mathrm{P}$ molar ratio of 1.67 (Fig. 1a; see also the closed triangles in Fig. 2). Moreover, the $\beta$-TCP content increased by adding water soluble $\left(\mathrm{NH}_{4}\right)_{2} \mathrm{HPO}_{4}$ (Fig. 1d), and phase pure $\beta$-TCP was obtained by thermal treatment at a $\mathrm{Ca} / \mathrm{P}$ molar ratio of 1.50 (Fig. 1e; see also the closed squares in Fig. 2). These results support our assumption that the $\mathrm{Ca}$ or $\mathrm{PO}_{4}$ salts were homogeneously distributed in the nanopores of nanoparticle-assembled CDHAp, and that they homogeneously reacted with CDHAp. Hereafter, the BCP samples prepared in this study are abbreviated as $\mathrm{BCP}-\mathrm{XX}$, in which the numerical value (XX) indicates the $\beta$-TCP content (wt.\%).

<Fig. 1>

<Fig. 2> 


\subsection{Morphology of nanoporous BCP}

Before thermal treatment, all samples prepared with different $\mathrm{Ca} / \mathrm{P}$ ratios had nanosized pores $(\sim 8 \mathrm{~nm})$ on their surfaces (Supplementary Fig. S1), and the initial porosity was approximately $50 \%$ [26]. After thermal treatment at $1000^{\circ} \mathrm{C}$, the pore size on each sample surface increased to several hundred nanometers, and different $\mathrm{Ca} / \mathrm{P}$ ratios did not significantly alter the surface morphological characteristics of BCP (Fig. 3). The analysis of SEM images revealed that the surface porosities were almost the same (18-22\%) among the different $\mathrm{Ca} / \mathrm{P}$ samples (Table 1); however, the surface porosity tended to decrease as the $\mathrm{Ca} / \mathrm{P}$ ratio decreased. In addition, the sizes of the crystal grains measured from SEM images were also almost the same (210-300 nm) among the different $\mathrm{Ca} / \mathrm{P}$ samples (Table 1), but the size tended to increase slightly as the $\mathrm{Ca} / \mathrm{P}$ ratio decreased. These results suggest that the $\beta$-TCP component slightly promoted grain growth during thermal treatment. Previously, selective area electron diffraction (SAED) was used to show that TCP grains grow coarser $(\sim 0.5 \mu \mathrm{m})$ than HAp grains $(\sim 0.1 \mu \mathrm{m})$ in $\mathrm{BCP}(88 \% \mathrm{HAp}$ and $12 \% \beta$-TCP $)$ sintered at $1100^{\circ} \mathrm{C}$ and $20 \mathrm{MPa}$ for $30 \mathrm{~min}$ [30].

\section{<Fig. 3>}

\section{<Table 1>}

Mercury intrusion porosimetry was performed to quantitatively determine the pore-size distribution, porosity, and specific surface area of BCP samples. Figure 4 shows the pore-size distributions of the samples with different $\mathrm{Ca} / \mathrm{P}$ ratios after thermal treatment. For the sample prepared without additives (Ca/P molar ratio of 1.61$)$, the pore-size distribution was narrow and 
the mean pore size was $173 \mathrm{~nm}$ (Table 1). For the sample prepared with $\mathrm{Ca}\left(\mathrm{NO}_{3}\right)_{2}$ or $\left(\mathrm{NH}_{4}\right)_{2} \mathrm{HPO}_{4}$, the position of the apex was almost the same for all samples but an extended tail of smaller size was observed. The porosities and specific surface areas were significantly decreased, and the percentages of the closed pores were slightly increased in the samples prepared with both additives (Table 1).

\section{<Fig. 4>}

In our previous study [27], we showed that the pore size in nanoparticle-assembled CDHAp was enlarged after thermal treatment owing to void (pore) expansion and fusion by the increase in solid-state density of low-crystallinity CDHAp nanoparticles and the consolidation of the grains, respectively. Nanoporous or microporous BCPs have been also prepared from amorphous calcium phosphate [31,32] and low-crystallinity CDHAp [9,33,34], but the formation mechanism has not been investigated. Note that the compositions of BCPs in the above studies were controlled by the calcium deficiency of the as-prepared starting materials. The solid-state pressureless sintering behavior of HAp has been well investigated [30]. At the first stage of sintering (or thermal treatment at less than $\sim 800^{\circ} \mathrm{C}$ ), the surface area of HAp powder compacts begins to decrease without densification and the grains weld through the formation of strong chemical bonds, resulting in the appearance of necks between grains. In our previous study [27], we observed that the solid-state density of the CDHAp nanoparticles (2.85 $\mathrm{g} / \mathrm{cm}^{3}$ ) used as a building block linearly increased without significant densification below $800^{\circ} \mathrm{C}$. That is, the voids expanded at the first stage of thermal treatment according to the volumetric shrinkage of the nanoparticles that surrounded the voids. In this study, on the basis 
of the difference in the theoretical solid-state densities of HAp $\left(3.16 \mathrm{~g} / \mathrm{cm}^{3}\right.$ [13]) and $\beta$-TCP $\left(3.07 \mathrm{~g} / \mathrm{cm}^{3}[13]\right)$, slightly larger pores are likely to be formed with a larger $\mathrm{Ca} / \mathrm{P}$ ratio at the first stage of sintering. In the intermediate stage of sintering (or thermal treatment at greater than $\sim 800^{\circ} \mathrm{C}$ ), the pores are merged and the total volume of pores in HAp ceramics decreases [30]. Then the pores can disappear in the final stage of sintering from a thermodynamic viewpoint. We also observed significant reduction in the porosity (i.e., total pore volume) after thermal treatment at greater than $800^{\circ} \mathrm{C}$ [27]. Therefore, the nanosized pores observed in this study were kinetically formed. From a kinetic viewpoint, the thermal treatment temperature and time will significantly influence the fusion (interconnection) behavior of voids because higher temperature enhances the volume or grain-boundary diffusion [30], and hence, the diffusion of voids. The initial porosity (the number of pores), initial pore size, and initial pore configuration before thermal treatment are also likely to influence the fusion behavior of voids from a kinetic viewpoint. Therefore, to control the nanoporous structure (pore size, pore volume, and pore morphologies) inside $\mathrm{BCP}$ after thermal treatment, precise control of the nanoparticle configuration inside the initial nanoparticle-assembled CDHAp should be necessary. In this study, however, the porosity (i.e., percentage of pore volume) inside BCP decreased significantly and the closed pores increased slightly by the addition of two salt types (Table 1). These results suggest that the nanoparticles inside the nanoparticle-assembled CDHAp were packed more closely (and hence the particle coordination number increased) with the addition of the salts because the addition of $\mathrm{Ca}^{2+}$ or $\mathrm{PO}_{4}{ }^{3-}$ salt changes the $\zeta$-potential of HAp surfaces [29]. In addition, both $\mathrm{Ca}\left(\mathrm{NO}_{3}\right)_{2}\left(1 / 10\right.$, w/w vs. CDHAp) and $\left(\mathrm{NH}_{4}\right)_{2} \mathrm{HPO}_{4}(1 / 20$, w/w vs. CDHAp) enhanced the densification of BCP during the thermal treatment. Because $\mathrm{Ca}\left(\mathrm{NO}_{3}\right)_{2}$ melts at $561^{\circ} \mathrm{C}$ [35], the liquid phase might promote densification via liquid phase sintering 
[36,37]. As described above, the surface morphology (i.e., surface grain size and surface pore size) did not significantly differ between the samples. One reason may be that the nanoparticles were packed at the first stage of nanoparticle assembly (i.e., drying of the aqueous dispersion of CDHAp nanoparticles) and could be more closely packed on the surface of nanoparticle-assembled CDHAp plate compared with the inside (see Supplementary Fig. S1) owing to oil/water interfacial tension during nanoparticle assembly [26]. Another reason may be the result of the preferential decomposition of $\mathrm{Ca}\left(\mathrm{NO}_{3}\right)_{2}$ (at $\sim 680^{\circ} \mathrm{C}$ [35]) into $\mathrm{CaO}$ (melting point, $2850^{\circ} \mathrm{C}$ ) on the sample surfaces.

\subsection{Cell adhesion and differentiation on nanoporous BCP}

Initial cell adhesion tests on composition-controlled nanoporous calcium phosphates with similar surface morphology were conducted with MC3T3-E1 mouse preosteoblast cells after culture for $3 \mathrm{~h}$ (Figs. 5 and 6). In this study, a commercially available dense HAp and a tissue culture polystyrene were used as control samples. Cell differentiation was also evaluated with ALP staining after culturing MC3T3-E1 cells on each sample in a differentiation medium (Fig. 7).

The nanoporous HAp showed significantly improved initial cell adhesion compared with dense HAp ( $p<0.05$; Fig. 5). From the morphological observation via the SEM, the cells that adhered to the nanoporous HAp (Fig. 6b) were elongated with a fusiform fibroblastic appearance, unlike those on the dense HAp (Fig. 6a). These results support that osteoblastic cells adhesion was affected by not only the chemistry of HAp but also the surface topography, such as the degree of roughness and microdomain structure, as has been previously observed [38-42]. Cell adhesion, proliferation, and detachment strength were sensitive to surface 
roughness, and these parameters increased with HAp roughness [41]. In addition, the structure and size of the phase-separated microdomains on the block copolymer, the blocks of which had different protein adhesion properties, influenced cell adhesion owing to the "capping control" of the membrane proteins on the cells [42].

\section{<Fig. 5>}

<Fig. 6>

Next, we compared the three types of nanoporous samples. Although no statistically significant differences were observed in initial cell adhesion among the nanoporous samples (Fig. 5; $\mathrm{p}=0.640$ for nano $\mathrm{BCP}-35$ vs. nano HAp; $\mathrm{p}=0.159$ for nano $\mathrm{BCP}-35$ vs. $\beta$-TCP), the cells on the nanoporous $\mathrm{BCP}-35$ or pure $\beta$-TCP surfaces had expanded cytoskeletons that exhibited spreading (Fig. 6c and 6d), which was in contrast to the elongated cells exhibiting a fusiform fibroblastic appearance on nanoporous pure HAp (Fig. 6b). ALP staining revealed that cell differentiation was greater on the nanoporous HAp than on the nanoporous BCP-35 and $\beta$-TCP. Previous in vitro work with MC3T3-E1 cells has shown that elevated levels of both extracellular $\mathrm{Ca}^{2+}$ and $\mathrm{PO}_{4}{ }^{3-}$ ions decrease cell viability [43-45]. Suzuki et al. reported that the $\mathrm{PO}_{4}$ concentration increased in Eagle's minimum essential medium supplemented with $10 \%$ FBS by decreasing the $\mathrm{Ca} / \mathrm{P}$ ratio of the $\mathrm{BCP}$, while the $\mathrm{Ca}$ concentration remained constant [46], and this might be the reason why cell differentiation on nanoporous $\mathrm{BCP}-35$ or $\beta$-TCP was suppressed compared with that on nanoporous HAp.

<Fig. 7> 
The BCP composition influences the degradation rate and osteogenic potency in vivo. Habibovic et al. obtained significantly more bone formation in goats by implanting BCP with a HAp/ $\beta$-TCP ratio of $88 / 12$ as compared to pure HAp, and they attributed this difference in bone formation to the different degradation rates of the materials [47]. Arinzeh et al. reported that in vivo human mesenchymal stem cell (hMSC) bone induction occurred at a faster rate with a BCP scaffold (HAp/ $\beta$-TCP ratio, 20/80) compared to that with the other formulations of more stable 100\%-HAp, HAp/ $\beta$-TCP (76/24, 63/37, 56/44), and fully degradable 100\% TCP [48]. Kurashina et al. reported that bone formation was only detected after implantation of porous BCP with a HAp/ $\beta$-TCP ratio of 70/30 [49]. The aforementioned results demonstrate that not only the chemical composition plays a critical role in bone tissue engineering but also parameters such as microstructure [50,51], specific surface area [47,52], and macrostructure [53], as well as host anatomy and physiology [52], are important. In vivo evaluation of the nanoporous calcium phosphates prepared in the present study is now being attempted, and the in vivo influence of differing $\mathrm{BCP}$ composition with similar surface morphology will be clarified in the near future.

\section{Conclusion}

In this study, we aimed to develop a simple colloidal process for preparing nanoporous BCPs with well-controlled compositions (HAp/ $\beta$-TCP ratios) and the same surface morphology (i.e., surface grain size, surface pore size, and surface porosity). This process requires no pore generation agents (i.e., surfactant micelles and porogens), and consists of (1) the preparation of an aqueous dispersion of low-crystallinity CDHAp nanoparticles used as a building block, (2) 
the adjustment of the $\mathrm{Ca} / \mathrm{P}$ molar ratio by dissolving $\mathrm{Ca}$ or $\mathrm{PO}_{4}$ salts in the aqueous dispersion, (3) the preparation of the nanoparticle-assembled plates by drying the nanoparticle dispersion, and (4) the thermal treatment of the nanoparticle-assembled plates. Although we prepared nanoporous BCPs in a plate form in this study, this process is also applicable for granules and macroporous forms prepared via colloidal processes, such as spray drying and the polymer sponge method. The results showed that the HAp/ $\beta$-TCP ratio of BCP could be readily controlled without significantly altering the surface morphology of nanoporous BCP. However, the porosity significantly decreased with adjustment of the $\mathrm{Ca} / \mathrm{P}$ molar ratio, which suggests that more precise control of the initial packing state of the nanoparticles (and hence the initial characteristics of pores such as the pore size, the number of pores, and the configuration of pores) of the nanoparticle-assembled CDHAp is necessary to precisely control the overall porous structure after thermal treatment. The nanoporous BCP ceramics developed in this study have potential applications in orthopedics, dentistry, and tissue engineering. Our final goal is to develop a novel artificial bone graft for alveolar cleft repair in children with cleft lip or cleft lip and palate. Although this study focused on calcium phosphates, this approach can be applied in the fabrication of mesoporous (or nanoporous) materials with other fine ceramics for use as ceramic catalysts and photonic band gap crystals.

\section{Acknowledgments}

The SEM observations, XRD measurements, and in vitro tests were performed at the Institute of Dental Research, Osaka Dental University. This study was supported in part by JSPS KAKENHI Grant Number 23792301 and by a grant program of the Feasibility Study

Stage in Adaptable and Seamless Technology Transfer Program through Target-driven R\&D 
(A-STEP; ID: AS231Z01647C) from the Japan Science and Technology Agency (JST).

\section{Supplementary material}

The online version of this article contains additional supplementary material. 


\section{REFERENCES}

[1] S.V. Dorozhkin, Biphasic, triphasic and multiphasic calcium orthophosphates, Acta Biomater. 8 (2012) 963-977.

[2] S. Bose, S. Tarafder, Calcium phosphate ceramic systems in growth factor and drug delivery for bone tissue engineering: A review, Acta Biomater. 8 (2012) 1401-1421.

[3] G. Daculsi, S. Baroth, R.Z. LeGeros, 20 years of biphasic calcium phosphate bioceramics development and applications, in: R. Narayan, P. Colombo, D. Singh, J. Salem (Eds.), Advance in bioceramics and porous ceramics II, Wiley-American Ceramic Society, New York, 2010, pp. 45-58.

[4] M. Jarcho, Calcium phosphate ceramics as hard tissue prosthetics. Clin. Orthop. Relat. Res. 157 (1981) 259-278.

[5] R.F. Ellinger, E.B. Nery, K.L. Lynch, Histological assessment of periodontal osseous defects following implantation of hydroxyapatite and biphasic calcium phosphate ceramics: a case report, Int. J. Periodont. Restor. Dent. 3 (1986) 223-233.

[6] E.B.Nery, K.K. Lee, S. Czajkowski, J.J. Dooner, M. Duggan, R.F. Ellinger, J.M. Henskin, R. Hines, M. Miller, J.W. Olson, M. Rafferty, T. Sullivan, P. Walters, D. Welch, A. Williams, A Veterans, Administration Cooperative Study of biphasic calcium phosphate ceramic in periodontal osseous defects, J. Periodontol. 61 (1990) 737-744.

[7] G. Daculsi, R.Z. Legeros, E. Nery, K. Lynch, B. Kerebel, Transformation of biphasic calcium phosphate ceramics in vivo: Ultrastructural and physicochemical characterization, J. Biomed. Mater. Res. 23 (1989) 883-894.

[8] E.B. Nery, R.Z. LeGeros, K.L. Lynch, K. Lee, Tissue response to biphasic calcium phosphate ceramic with different ratios of HA/beta TCP in periodontal osseous defects, J. 
Periodontol. 63 (1992) 729-735.

[9] R.Z. LeGeros, S. Lin, R. Rohanizadeh, D. Mijares, J.P. LeGeros, Biphasic calcium phosphate bioceramics: preparation, properties and applications, J. Mater. Sci. Mater. Med. 14 (2003) 201-209.

[10] S. Raynaud, E. Champion, D. Bernache-Assollant, P. Thomas, Calcium phosphate apatites with variable $\mathrm{Ca} / \mathrm{P}$ atomic ratio $\mathrm{I}$. Synthesis, characterisation and thermal stability of powders, Biomaterials 23 (2002) 1065-1072.

[11] A.K. Guha, S. Singh, R. Kumaresan, S. Nayar, A. Sinha, Mesenchymal cell response to nanosized biphasic calcium phosphate composites, Colloids Surf. B Biointerfaces 73 (2009) 146-151.

[12] M. Okada, T. Furuzono, Hydroxylapatite nanoparticles: fabrication methods and medical applications, Sci. Technol. Adv. Mater. 13 (2012) 064103.

[13] M. Descamps, L. Boilet, G. Moreau, A. Tricoteaux, J. Lu, A. Leriche, V. Lardot, F. Cambier, Processing and properties of biphasic calcium phosphates bioceramics obtained by pressureless sintering and hot isostatic pressing, J. Eur. Ceram. Soc. 33 (2013) $1263-1270$.

[14] X. Yang, Z. Wang, Synthesis of biphasic ceramics of hydroxyapatite and $\beta$-tricalcium phosphate with controlled phase content and porosity, J. Mater. Chem. 8 (1998) $2233-2237$.

[15] T.R. Tadjiev, C. Sungsu, K. Sukyoung, Mechano-Chemical Synthesis of Biphasic Calcium Phosphates with the Various Ratio of HA and $\beta$-TCP, Key Eng. Mater. 330-332 (2007) 7-10.

[16] R.R. Rao, H.N. Roopa, T.S. Kannan, Solid state synthesis and thermal stability of HAP 
and HAP- $\beta$-TCP composite ceramic powders, J. Mater. Sci. Mater. Med. 8 (1997) $511-518$.

[17] C.-K. Hsu, The preparation of biphasic porous calcium phosphate by the mixture of $\mathrm{Ca}\left(\mathrm{H}_{2} \mathrm{PO}_{4}\right)_{2} \cdot \mathrm{H}_{2} \mathrm{O}$ and $\mathrm{CaCO}_{3}$, Mater. Chem. Phys. 80 (2003) 409-420.

[18] K.S. Jaw, Preparation of a biphasic calcium phosphate from $\mathrm{Ca}\left(\mathrm{H}_{2} \mathrm{PO}_{4}\right)_{2} \cdot \mathrm{H}_{2} \mathrm{O}$ and $\mathrm{CaCO}_{3}$, J. Therm. Anal. Calorim. 83 (2006) 145-149.

[19] M. Ebrahimi, P. Pripatnanont, N. Monmaturapoj, S. Suttapreyasri, Fabrication and characterization of novel nano hydroxyapatite/ $\beta$-tricalcium phosphate scaffolds in three different composition ratios, J. Biomed. Mater. Res. A 100 (2012) 2260-2268.

[20] S. Impens, R. Schelstraete, J. Luyten, S. Mullens, I. Thijs, J. van Humbeeck, J. Schrooten, Production and characterisation of porous calcium phosphate structures with controllable hydroxyapatite/ $\beta$-tricalcium phosphate ratios, Adv. Appl. Ceram. 108 (2009) 494-500.

[21] T. J. Webster, C. Ergun, R. H. Doremus, R. W. Siegel, R. Bizios, Enhanced osteoclast-like cell functions on nanophase ceramics, Biomaterials 22 (2001) 1327-1333.

[22] G. Balasundaram, M. Sato, T. J. Webster, Using hydroxyapatite nanoparticles and decreased crystallinity to promote osteoblast adhesion similar to functionalizing with RGD, Biomaterials 27 (2006) 2798-2805.

[23] W. Sun, C. Chu, J. Wang, H. Zhao, Comparison of periodontal ligament cells responses to dense and nanophase hydroxyapatite, J. Mater. Sci. Mater. Med. 18 (2007) 677-683.

[24] J. Huang, S. M. Best, W. Bonfield, R. A. Brooks, N. Rushton, S. N. Jayasinghe, M. J. Edirisinghe, In vitro assessment of the biological response to nano-sized hydroxyapatite, J. Mater. Sci. Mater. Med. 15 (2004) 441-445.

[25] M.R. Appleford, S. Oh, N. Oh, J.L. Ong, In vivo study on hydroxyapatite scaffolds with 
trabecular architecture for bone repair, J. Biomed. Mater. Res. A 89 (2009) 1019-1027.

[26] M. Okada, T. Furuzono, Low-temperature synthesis of nanoparticle-assembled, transparent, and low-crystallized hydroxyapatite blocks, J. Colloid Interface Sci. 360 (2011) 457-462.

[27] M. Okada, K. Fujiwara, M. Uehira, N. Matsumoto, S. Takeda, Expansion of nanosized pores in low-crystallinity nanoparticle-assembled plates via a thermally induced increase in solid-state density, J. Colloid Interface Sci. 405 (2013) 58-63.

[28] Ir. R. Rutgers, Relative Viscosity and Concentration, Rheol. Acta. 2 (1962) 305-348.

[29] P. Somasundaran, Y. H. C. Wang, Surface chemical characteristics and adsorption properties of apatite.in: D. N. Misra (Ed.), Adsorption on and Surface Chemistry of Hydroxyapatite, Plenum Press, New York, 1984, pp. 129-149.

[30] E. Champion, Sintering of calcium phosphate bioceramics, Acta Biomater. 9 (2013) $5855-5875$.

[31] P. Layrolle, A. Lebugle, Characterization and reactivity of nanosized calcium phosphates prepared in anhydrous ethanol, Chem. Mater. 6 (1994) 1996-2004.

[32] B.H. Fellah, P. Layrolle, Sol-gel synthesis and characterization of macroporous calcium phosphate bioceramics containing microporosity, Acta Biomater. 5 (2009) 735-742.

[33] N. Kivrak, C. Tas, Synthesis of calcium hydroxyapatite-tricalcium phosphate (HA-TCP) composite bioceramic powders and their sintering behavior, J. Am. Ceram. Soc. 81 (1998) 2245-2252.

[34] S. Langstaff, M. Sayer, T.J.N Smith, S.M. Pugh, S.A.M. Hesp, W.T. Thompson, Resorbable bioceramics based on stabilized calcium phosphates. Part I: rational design, sample preparation and material characterization, Biomaterials 20 (1999) 1727-1741. 
[35] C. Ettarh, A.K. Galwey, A kinetic and mechanistic study of the thermal decomposition of calcium nitrate, Thermochim. Acta, 288 (1996) 203-219.

[36] W.D. Kingery, Densification during Sintering in the Presence of a Liquid Phase. I. Theory, J. Appl. Phys. 30 (1959) 301-306.

[37] J.E. Marion, C.H. Hsueh, A.G. Evans, Liquid Phase Sintering of Ceramics, J. Am. Ceram. Soc. 70 (1987) 708-713.

[38] K. Anselme, M. Bigerelle, B. Noel, E. Dufresne, D. Judas, A. Iost, P. Hardouin, Qualitative and quantitative study of human osteoblast adhesion on materials with various surface roughnesses, J. Biomed. Mater. Res. 49 (2000) 155-166.

[39] K. Anselme, M. Bigerelle, Topography effects of pure titanium substrates on human osteoblast long-term adhesion, Acta Biomater. 1 (2005) 211-222.

[40] N. Ribeiro, S.R. Sousa, F.J. Monteiro, Influence of crystallite size of nanophased hydroxyapatite on fibronectin and osteonectin adsorption and on MC3T3-E1 osteoblast adhesion and morphology, J. Colloid Interface Sci. 351 (2010) 398-406.

[41] D.D. Deligianni, N.D. Katsala, P.G. Koutsoukos, Y.F. Missirlis, Effect of surface roughness of hydroxyapatite on human bone marrow cell adhesion, proliferation, differentiation and detachment strength, Biomaterials 22 (2001) 87-96.

[42] T. Okano, M. Uruno, N. Sugiyama, M. Shimada, I. Shinohara, K. Kataoka, Y. Sakurai, Suppression of platelet activity on microdomain surfaces of 2-hydroxyethyl methacrylate-polyether block copolymers, J. Biomed. Mater. Res. 20 (1986) 1035-1047.

[43] Z. Meleti, I.M. Shapiro, C.S. Adams, Inorganic Phosphate Induces Apoptosis of Osteoblast-like Cells in Culture, Bone 27 (2000) 359-366.

[44] C.S. Adams, K. Mansfield, R.L. Perlot, I.M. Shapiro, Matrix Regulation of Skeletal Cell 
Apoptosis. Role of calcium and phosphate ions, J. Biol. Chem. 276 (2001) 20316-20322.

[45] E.J. Tsang, C.K. Arakawa, P.A. Zuk, B.M. Wu, Osteoblast Interactions Within a Biomimetic Apatite Microenvironment, Ann. Biomed. Eng. 39 (2011) 1186-1200.

[46] T. Suzuki, T. Yamamoto, M. Toriyama, K. Nishizawa, Y. Yokogawa, M.R. Mucalo, Y. Kawamoto, F. Nagata, T. Kameyama, Surface instability of calcium phosphate ceramics in tissue culture medium and the effect on adhesion and growth of anchorage-dependent animal cells, J. Biomed. Mater. Res. 34 (1997) 507-517.

[47] P. Habibovic, H. Yuan, C. M. van der Valk, G. Meijer, C. A. van Blitterswijk, K. de Groot, 3D microenvironment as essential element for osteoinduction by biomaterials, Biomaterials 26 (2005) 3565-3575.

[48] T.L. Arinzeh, T. Tran, J. Mcalary, G. Daculsi, A comparative study of biphasic calcium phosphate ceramics for human mesenchymal stem-cell-induced bone formation, Biomaterials 26 (2005) 3631-3638.

[49] K. Kurashina, H. Kurita, Q. Wu, A. Ohtsuka, H. Kobayashi, Ectopic osteogenesis with biphasic ceramics of hydroxyapatite and tricalcium phosphate in rabbits, Biomaterials 23 (2002) 407-412.

[50] K.A. Hing, B. Annaz, S. Saeed, P.A. Revell, T. Buckland, Microporosity enhances bioactivity of synthetic bone graft substitutes, J. Mater. Sci. Mater. Mad. 6 (2005) $467-475$.

[51] D. Le Nihouannen, G. Daculsi, A. Saffarzadeh, O. Gauthier, S. Delplace, P. Pilet, P. Layrolle, Ectopic bone formation by microporous calcium phosphate ceramic particles in sheep muscles, Bone 36 (2005) 1086-1093.

[52] B. H. Fellah, O. Gauthier, P. Weiss, D. Chappard, P. Layrolle, Osteogenicity of biphasic 
calcium phosphate ceramics and bone autograft in a goat model, Biomaterials 29 (2008) $1177-1188$.

[53] M. Mastrogiacomo, S. Scaglione, R. Martinetti, L. Dolcini, F. Beltrame, R. Cancedda, R. Quarto, Role of scaffold internal structure on in vivo bone formation in macroporous calcium phosphate bioceramics, Biomaterials 27 (2006) 3230-3237. 


\section{FIGURE CAPTIONS}

Figure 1. XRD patterns of nanoparticle-assembled CDHAp after thermal treatment at $1000^{\circ} \mathrm{C}$. The CDHAp samples were prepared by drying CDHAp dispersions with added $\mathrm{Ca}\left(\mathrm{NO}_{3}\right)_{2}$ or $\left(\mathrm{NH}_{4}\right)_{2} \mathrm{HPO}_{4}$ to adjust $\mathrm{Ca} / \mathrm{P}$ molar ratios: (a) 1.67, (b) 1.64, (c) 1.61 (without additives), (d) 1.56, and (e) 1.50 .

Figure 2. $\beta$-TCP contents of nanoparticle-assembled CDHAp prepared with different $\mathrm{Ca} / \mathrm{P}$ ratios after thermal treatment at $1000^{\circ} \mathrm{C}$. The CDHAp samples were prepared $(\mathrm{O})$ without and with additives: $\boldsymbol{\Lambda}, \mathrm{Ca}\left(\mathrm{NO}_{3}\right)_{2} ; \boldsymbol{\square},\left(\mathrm{NH}_{4}\right)_{2} \mathrm{HPO}_{4}$.

Figure 3. SEM photographs of nanoparticle-assembled CDHAp after thermal treatment at $1000^{\circ} \mathrm{C}$. The CDHAp samples were prepared by drying CDHAp dispersions with added $\mathrm{Ca}\left(\mathrm{NO}_{3}\right)_{2}$ and $\left(\mathrm{NH}_{4}\right)_{2} \mathrm{HPO}_{4}$ to adjust the $\mathrm{Ca} / \mathrm{P}$ molar ratios: (a) 1.67, (b) 1.61 (without additives), and (c) 1.50 .

Figure 4. Pore size distributions in nanoparticle-assembled CDHAp after thermal treatment at $1000^{\circ} \mathrm{C}$. The CDHAp samples were prepared by drying CDHAp dispersions with added $\mathrm{Ca}\left(\mathrm{NO}_{3}\right)_{2}$ and $\left(\mathrm{NH}_{4}\right)_{2} \mathrm{HPO}_{4}$ to adjust $\mathrm{Ca} / \mathrm{P}$ molar ratios: (a) 1.67, (b) 1.61 (without additives), and (c) 1.50 .

Figure 5. Initial MC3T3-E1 cell adhesion after 3-h incubation on (a) dense HAp, (b) nanoporous HAp, (c) nanoporous BCP-35, (d) nanoporous $\beta$-TCP, and (e) tissue culture polystyrene. Initial cell density was 780 cells $/ \mathrm{mm}^{2}$. Error bars indicate standard errors $(n=5)$. Figure 6. SEM photographs of MC3T3-E1 cells after 3-h incubation on (a) dense HAp, (b) nanoporous HAp, (c) nanoporous $\mathrm{BCP}-35$, (d) nanoporous $\beta$-TCP, and (e) tissue culture polystyrene. The photographs (a')-(e') show magnified images.

Figure 7. Alkaline phosphatase staining of cells incubated on the samples in differentiation 
media for the indicated culture times. 
Table 1. Characteristics of nanoporous BCPs

\begin{tabular}{|l|c|c|c|c|c|c|c|}
\hline & $\begin{array}{c}\text { Grain size } \\
(\mathrm{nm})\end{array}$ & $\begin{array}{c}\text { Surface } \\
\text { porosity } \\
(\%)\end{array}$ & $\begin{array}{c}\text { Mean } \\
\text { pore size } \\
(\mathrm{nm})\end{array}$ & $\begin{array}{c}\text { Specific } \\
\text { surface area }^{f)} \\
\left(\mathrm{m}^{2} / \mathrm{g}\right)\end{array}$ & $\begin{array}{c}\text { Open } \\
\text { porosity } \\
(\%)\end{array}$ & $\begin{array}{c}\text { Apparent } \\
\text { density }^{f)} \\
\left(\mathrm{g} / \mathrm{cm}^{3}\right)\end{array}$ & $\begin{array}{c}\text { Closed } \\
\text { pores }^{f)} \\
\left(\text { vol. }^{\prime}\right)\end{array}$ \\
\hline $\mathrm{HAp}^{a)}$ & $210 \pm 60$ & $21.9 \pm 0.6$ & 157 & 2.3 & 20 & 3.073 & 2.8 \\
\hline${\mathrm{BCP}-35^{b)}}^{b}$ & $229 \pm 67$ & $19.3 \pm 1.1$ & 173 & 8.4 & 53 & 3.097 & 1.0 \\
\hline$\beta-\mathrm{TCP}^{c)}$ & $304 \pm 105$ & $17.9 \pm 1.0$ & 143 & 1.8 & 14 & 3.008 & 2.0 \\
\hline
\end{tabular}

${ }^{a)}$ Prepared with $\mathrm{Ca}\left(\mathrm{NO}_{3}\right)_{2}(\mathrm{Ca} / \mathrm{P}=1.67$, molar ratio)

${ }^{b)}$ Prepared without additives ( $\beta$-TCP content, 35 wt.\%)

${ }^{c)}$ Prepared with $\left(\mathrm{NH}_{4}\right)_{2} \mathrm{HPO}_{4}(\mathrm{Ca} / \mathrm{P}=1.50$, molar ratio $)$

${ }^{d)}$ Measured from SEM images; presented as means \pm standard deviations of the mean $(n=50)$

${ }^{e)}$ Percentage of pore region area in total area measured from SEM images; presented as means \pm standard deviations for the mean $(n=3)$

${ }^{\text {f) }}$ Measured via mercury intrusion porosimetry

${ }^{g)}$ Calculated from the apparent density of the sample and the theoretical density of HAp $\left(3.16 \mathrm{~g} / \mathrm{cm}^{3}\right), \beta$-TCP $\left(3.07 \mathrm{~g} / \mathrm{cm}^{3}\right)$, or BCP-35 $\left(3.13 \mathrm{~g} / \mathrm{cm}^{3}\right.$, calculated from the $\beta$-TCP content) 


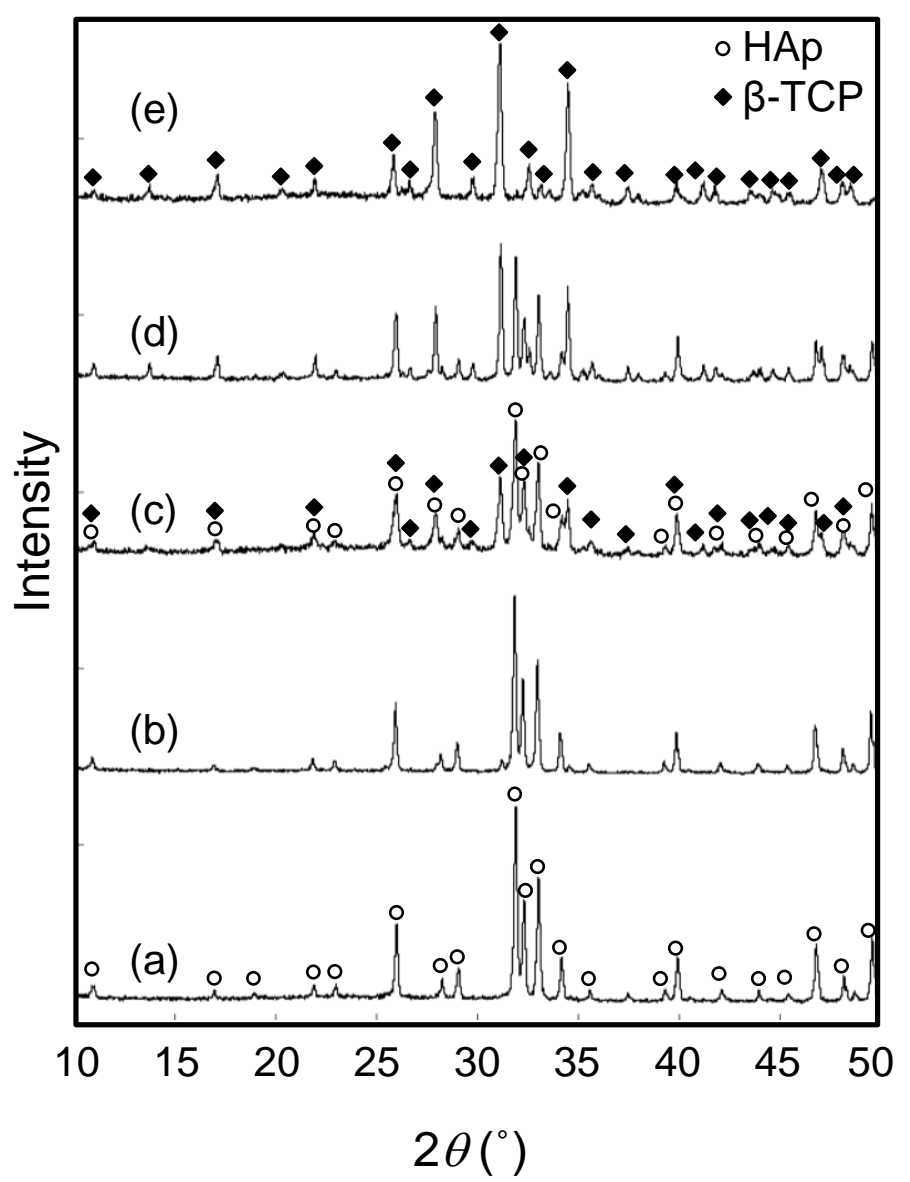

Figure 1. XRD patterns of nanoparticle-assembled CDHAp after thermal treatment at $1000^{\circ} \mathrm{C}$. The CDHAp samples were prepared by drying CDHAp dispersions with added $\mathrm{Ca}\left(\mathrm{NO}_{3}\right)_{2}$ or $\left(\mathrm{NH}_{4}\right)_{2} \mathrm{HPO}_{4}$ to adjust $\mathrm{Ca} / \mathrm{P}$ molar ratios: (a) 1.67 , (b) 1.64 , (c) 1.61 (without additives), (d) 1.56, and (e) 1.50. 


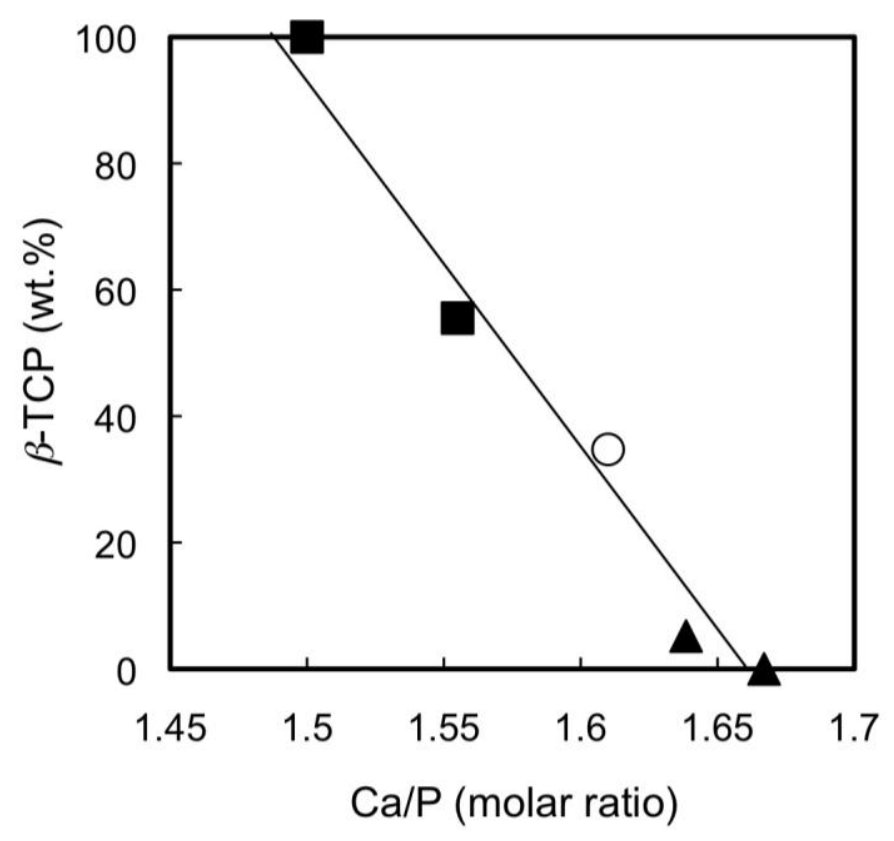

Figure 2. $\beta$-TCP contents of nanoparticle-assembled CDHAp prepared with different $\mathrm{Ca} / \mathrm{P}$ ratios after thermal treatment at $1000^{\circ} \mathrm{C}$. The CDHAp samples were prepared $(\bigcirc)$ without and with additives: $\boldsymbol{\Delta}, \mathrm{Ca}\left(\mathrm{NO}_{3}\right)_{2} ; \mathbf{\square},\left(\mathrm{NH}_{4}\right)_{2} \mathrm{HPO}_{4}$. 

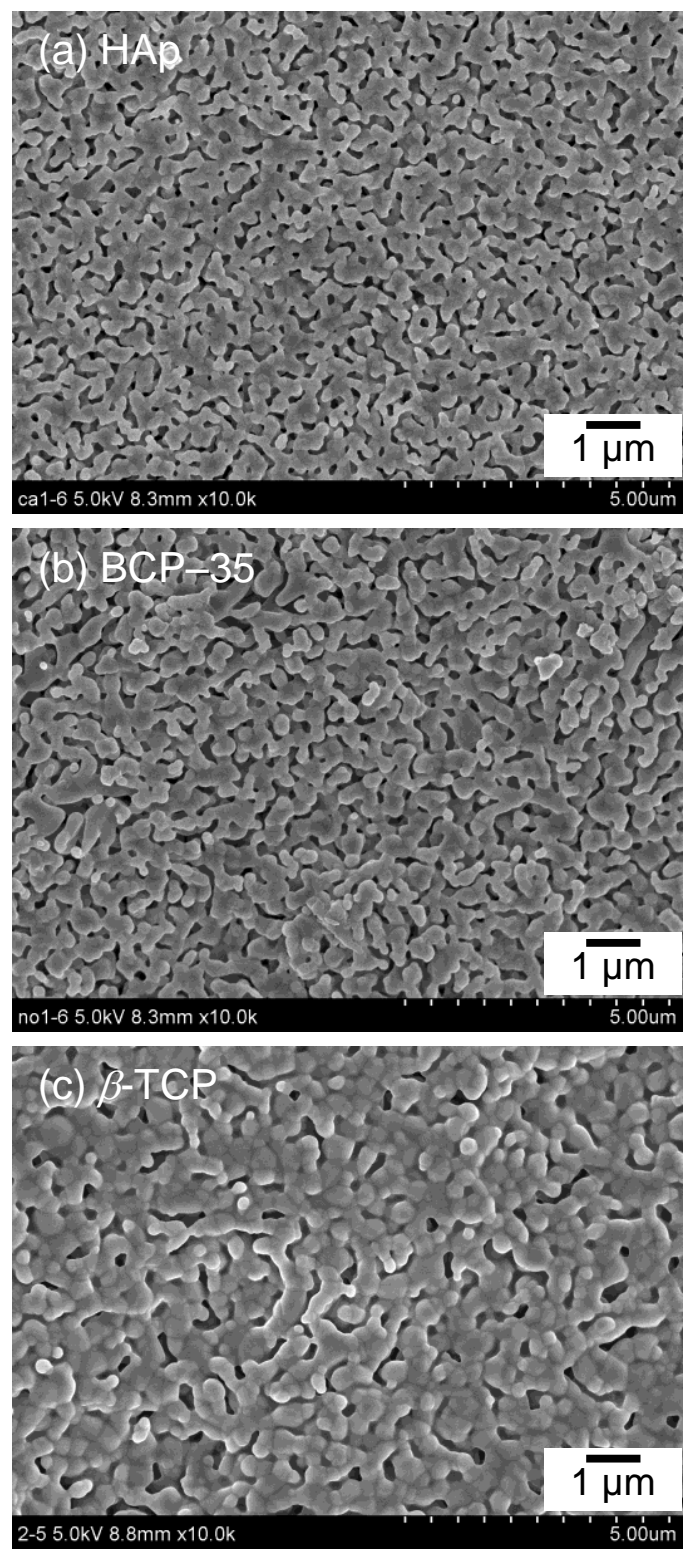

Figure 3. SEM photographs of nanoparticle-assembled CDHAp after thermal treatment at $1000^{\circ} \mathrm{C}$. The CDHAp samples were prepared by drying CDHAp dispersions with added $\mathrm{Ca}\left(\mathrm{NO}_{3}\right)_{2}$ and $\left(\mathrm{NH}_{4}\right)_{2} \mathrm{HPO}_{4}$ to adjust the $\mathrm{Ca} / \mathrm{P}$ molar ratios: (a) 1.67 , (b) 1.61 (without additives), and (c) 1.50 . 


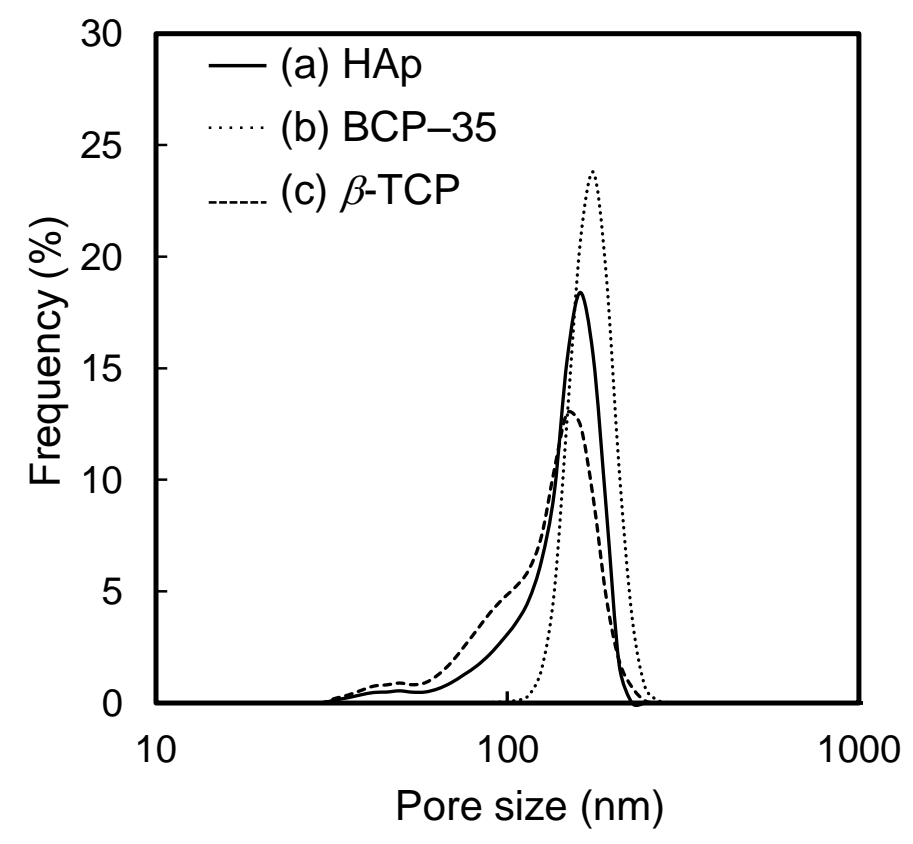

Figure 4. Pore size distributions in nanoparticle-assembled CDHAp after thermal treatment at $1000^{\circ} \mathrm{C}$. The CDHAp samples were prepared by drying CDHAp dispersions with added $\mathrm{Ca}\left(\mathrm{NO}_{3}\right)_{2}$ and $\left(\mathrm{NH}_{4}\right)_{2} \mathrm{HPO}_{4}$ to adjust $\mathrm{Ca} / \mathrm{P}$ molar ratios: (a) 1.67, (b) 1.61 (without additives), and (c) 1.50 . 


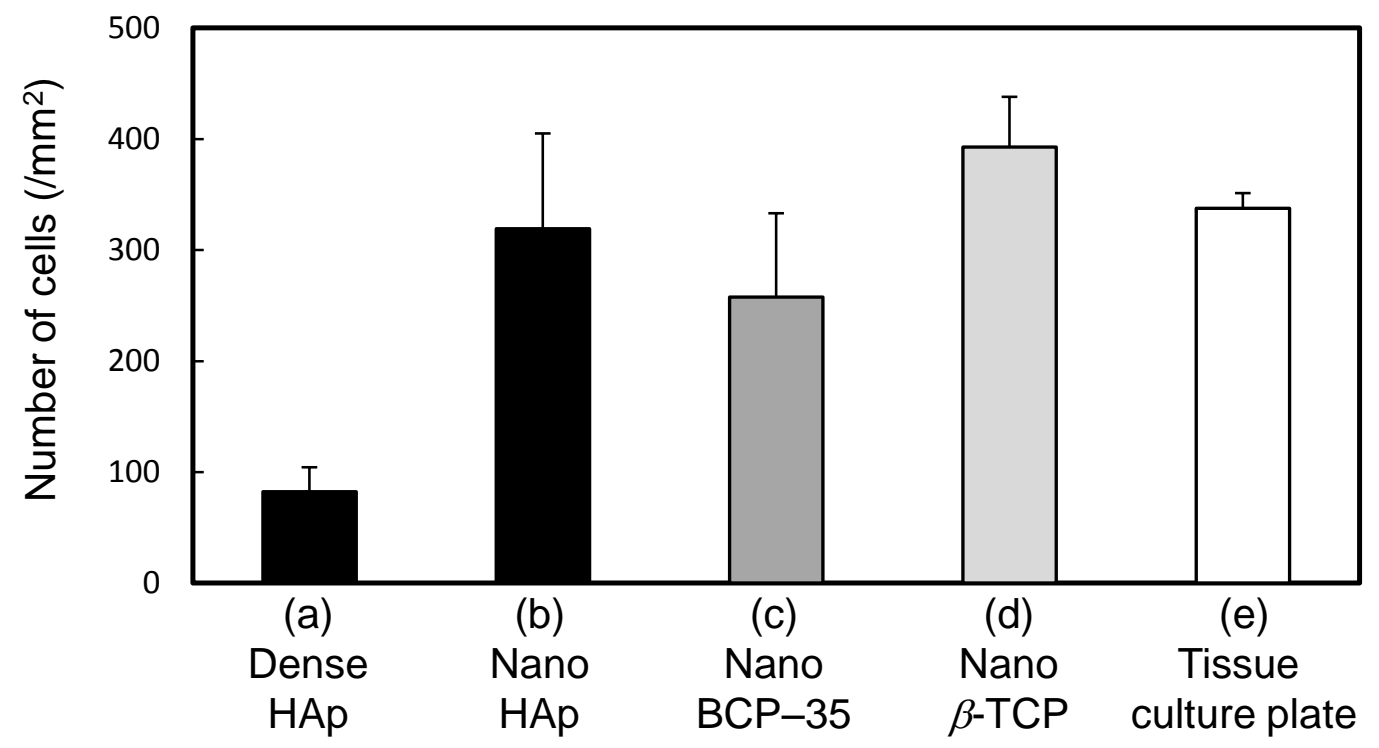

Figure 5. Initial MC3T3-E1 cell adhesion after 3-h incubation on (a) dense HAp, (b) nanoporous HAp, (c) nanoporous BCP-35, (d) nanoporous $\beta$-TCP, and (e) tissue culture polystyrene. Initial cell density was 780 cells $/ \mathrm{mm}^{2}$. Error bars indicate standard errors $(n=$ $5)$. 


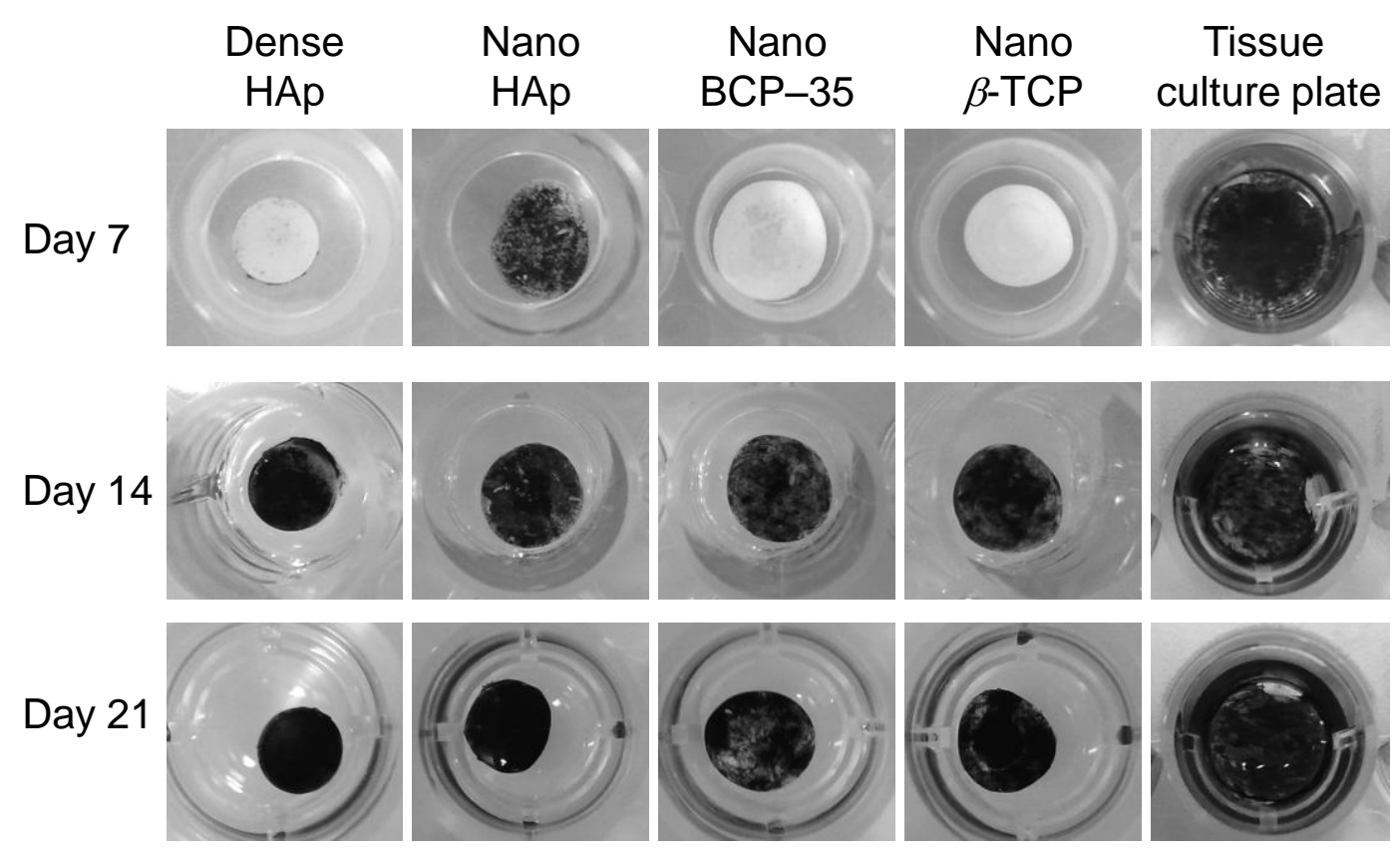

Figure 7. Alkaline phosphatase staining of cells incubated on the samples in differentiation media for the indicated culture times . 


\section{Graphical abstract}

Low crystallinity calcium-deficient hydroxyapatite nanoparticle assembly (having pores between the particles)

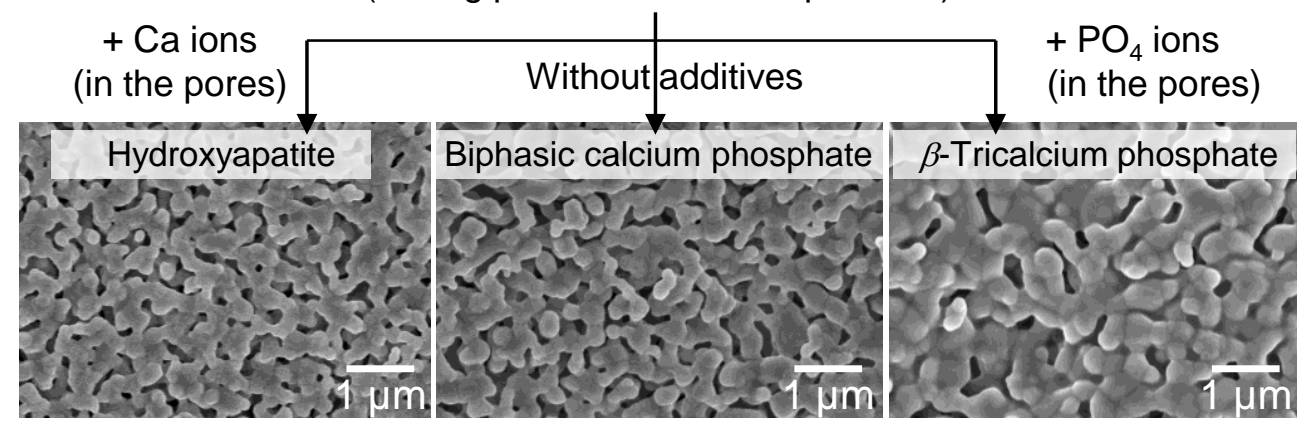

